\title{
Ascending aortic dilatation as a late complication after implantation of a mechanical aortic valve performed 37 years earlier
}

\author{
Piotr Zając, Michał Plewka, Waldemar Rogowski, Jarosław D. Kasprzak \\ Department of Cardiology, Medical University of Łódź, Poland
}

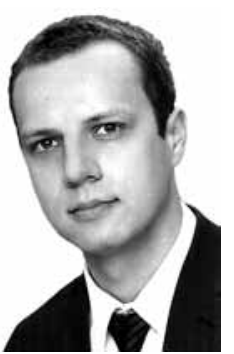

Kardiochirurgia i Torakochirurgia Polska 2014; 11 (4): 437-440

\begin{abstract}
Aortic stenosis (AS) is the third most common cardiovascular disease. Aortic valve replacement (AVR) is the only effective method of treatment in most AS patients. In some patients, AS leads to poststenotic dilatation of the ascending aorta - most commonly, this occurs in patients with concurrent aortic regurgitation or bicuspid aortic valve (BAV) and in patients after aortic valve replacement. Cardiac surgeons face the dilemma whether to perform concurrent replacement of the dilated ascending aorta in patients qualified for AVR, as it is associated with an increased risk of perioperative complications and mortality. We report a case of a patient with an ascending aortic aneurysm, who had been implanted with an aortic mechanical valve (Lillehei-Kaster 16 ECC) 37 years earlier.
\end{abstract}

Key words: prosthetic aortic valve, ascending aortic aneurysm.

\section{Introduction}

Aortic valve stenosis (AS) is the third most common disease of the cardiovascular system. Aortic valve replacement (AVR) remains the only effective method of treatment in most AS patients in spite of the development of new, less invasive treatments. This study presents the case of a patient who had been implanted with a mechanical aortic valve (Lillehei-Kaster 16 ECC) 37 years before the described admission due to late complications in the form of an ascending aortic aneurysm and deterioration of valve function.

\section{Case study}

The 73-year-old patient was admitted electively to the clinic due to recurrent anginal complaints and exercise tolerance deterioration in order to undergo an invasive as-

\section{Streszczenie}

Zwężenie zastawki aortalnej (aortic stenosis - AS) jest trzecią najczęstszą chorobą układu sercowo-naczyniowego. Operacja wymiany zastawki (aortic valve replacement - AVR) nadal pozostaje jedyną formą skutecznej terapii dużej grupy chorych z AS. U części pacjentów ze stenozą aortalną dochodzi do postenotycznego poszerzenia aorty wstępującej - najczęściej u pacjentów ze wspótistniejącą niedomykalnością aortalną, dwupłatkową zastawką aortalną oraz po AVR. Jednocześnie istotny dylemat stanowi kardiochirurgiczna kwestia ewentualnej jednoczesnej operacji poszerzonej aorty wstępującej u pacjentów kwalifikowanych do AVR, co zwiększa ryzyko powikłań oraz śmiertelność okołooperacyjną. W pracy przedstawiono przypadek pacjentki z tętniakiem aorty wstępującej oraz wszczepioną 37 lat wcześniej w pozycji aortalnej sztuczną zastawką Lillehei-Kaster 16 ECC.

Słowa kluczowe: sztuczna zastawka aortalna, tętniak aorty wstępującej.

sessment of the coronary vessels before the planned cardiac surgery procedure involving the ascending aorta. In 1975 (i.e. 37 years earlier), the patient was implanted with a prosthetic valve (Lillehei-Kaster 16 ECC) due to aortic valve stenosis. For many years after the operation, the patient experienced no symptoms of heart failure. The first diagnosis of ascending aortic dilatation was made approximately 5 years ago after a control echocardiographic examination; based on the available records, it can be surmised that, at the time of the original valve replacement, the ascending aorta was probably not dilated (detailed records are lacking). The presently performed angio-CT examination demonstrated an ascending aortic aneurysm (dimensions: 58 $\times 60 \mathrm{~mm}$, increasing by approximately $1-2 \mathrm{~mm} /$ year). The patient's medical history also included moderate mitral and tricuspid regurgitation, arterial hypertension under pharmacological control, and type 2 diabetes mellitus. Echocar-

Address for correspondence: Piotr Zając, Department of Cardiology, Medical University of Łódź, 1/5 Kniaziewicza St., 91-347 Łódź, Poland, phone: +48 516170 685, e-mail: zjc.ptr@gmail.com 
diography demonstrated that the mobility of the disc of the prosthetic valve (Lillehei-Kaster 16) was restricted, and the flow through the valve was increased to $4 \mathrm{~m} / \mathrm{s}$ (gradient: max $62 \mathrm{mmHg}$, average $35 \mathrm{mmHg}$ ) (Fig. 1). It also revealed segmental contractility impairments of the left ventricular muscle in the form of hypokinesia of the interventricular septum and the posterior wall with ejection fraction (EF) at $52 \%$ and an ascending aortic aneurysm up to $59 \mathrm{~mm}$ in size (Fig. 2). Coronarography revealed a $90 \%$ constriction in the right coronary artery (Fig. 3). Fluoroscopy was performed, visualizing reduced opening of the aortic valve disc - up to 60 degrees (according to the manufacturer, the maximal opening angle should be 80 degrees) (Fig. 4). Due to the planned cardiac procedure, percutaneous coronary angioplasty was not performed. The patient was referred to the Clinic of Cardiac Surgery for further surgical treatment - replacement of the dilated ascending aorta and the mechanical aortic prosthesis with concurrent coronary revascularization (at the time of this study's completion, the patient is awaiting the procedure).

\section{Discussion}

In spite of the great advancements achieved in cardiac pharmacology, cardiac surgery remains the only effective method of treating severe aortic stenosis. The era of effective surgical treatment of cardiovascular diseases began with the introduction of the heart-lung machine in 1955.
In 1960, the first mechanical ball valve (Starr-Edwards) was implanted. The subsequently introduced mechanical valves included single disc (Lillehei-Kaster, Bjork-Shiley, Omniscience) and double disc (St. Jude Medical, CarboMedics) valves [1]. Concurrently, biological valves (Ionescu, Carpentier-Edwards) were being developed and improved. The next years saw attempts to create more durable and less thrombogenic valves with better hemodynamic parameters, that would require less invasive implantation procedures; this led to the development of such techniques as percutaneous aortic valve implantation.

The described patient was implanted with a LilleheiKaster 16 ECC prosthetic aortic valve in 1975 at the Clinic of Cardiac Surgery in Łódź - at the time, it was one of the most state-of-the-art (and least accessible) valves of this type. It included a tilting disc made of pyrolytic carbon, fixed on a titanium scaffold. The aim of its constructors was for the disc to open to an angle of 80 degrees [2]. The valve had better hemodynamic parameters and was less thrombogenic than the ball valves that had been used since the 1960s. In a study by Stewart et al. [3], which analyzed 273 patients implanted with Lillehei-Kaster mechanical valves (mean observation time: 4.6 years), the percentage of patients without the most common complications (such as thrombosis, embolisms, valve infections, or paravalvular leaks) was $90 \%$. The authors concluded that the valve is characterized by substantial mechanical durability

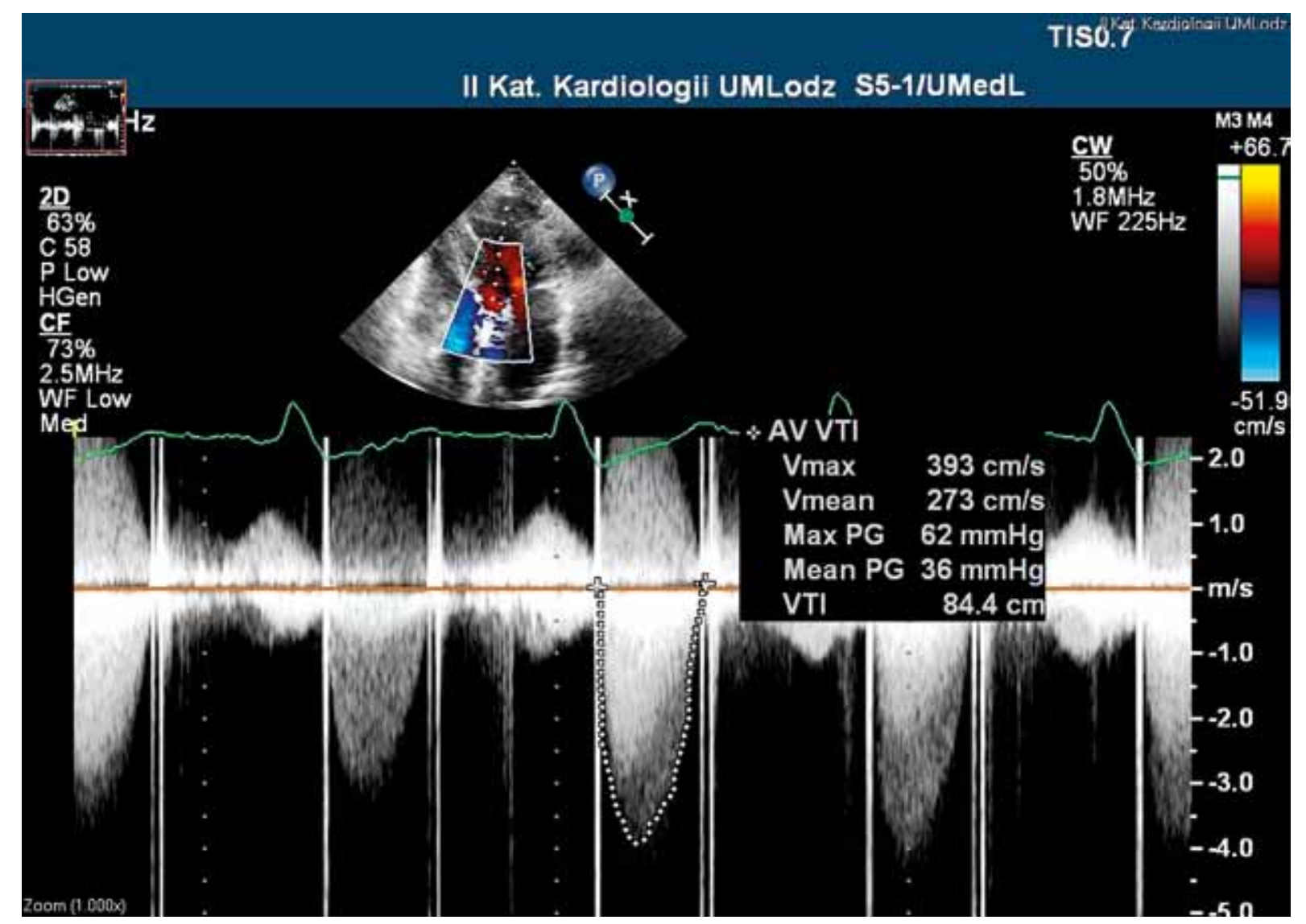

Fig. 1. Transthoracic echocardiogram, 5-chamber apical view: increased flow velocity through the disc of the mechanical aortic valve 


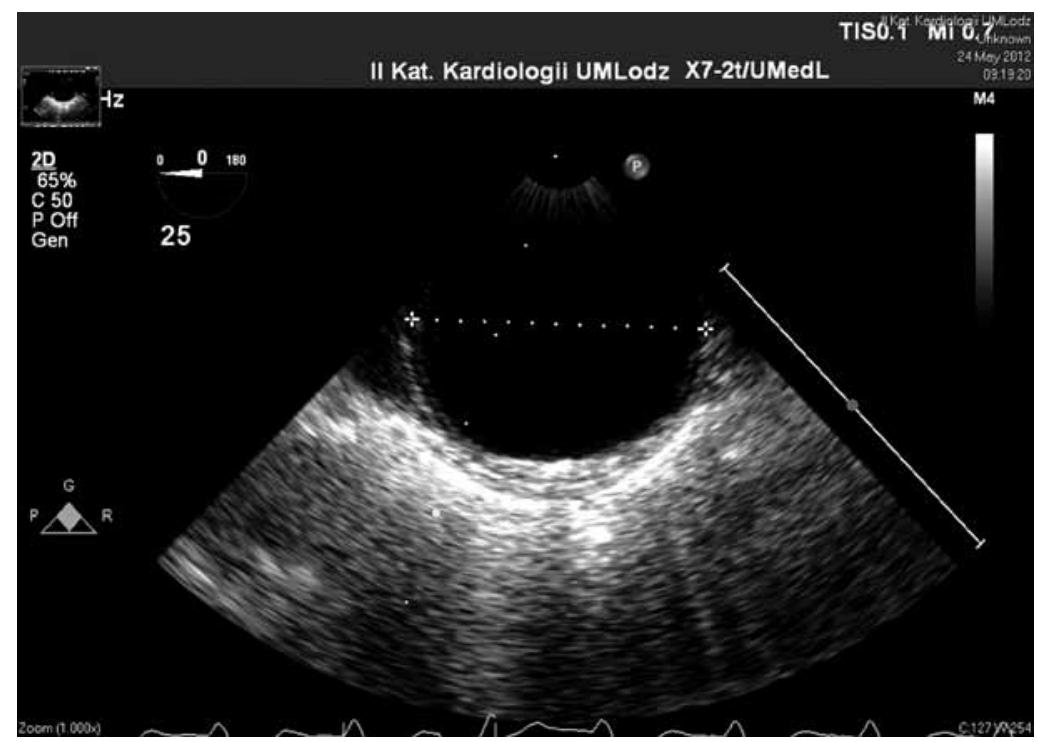

Fig. 2. Transesophageal echocardiogram: ascending aortic dilatation

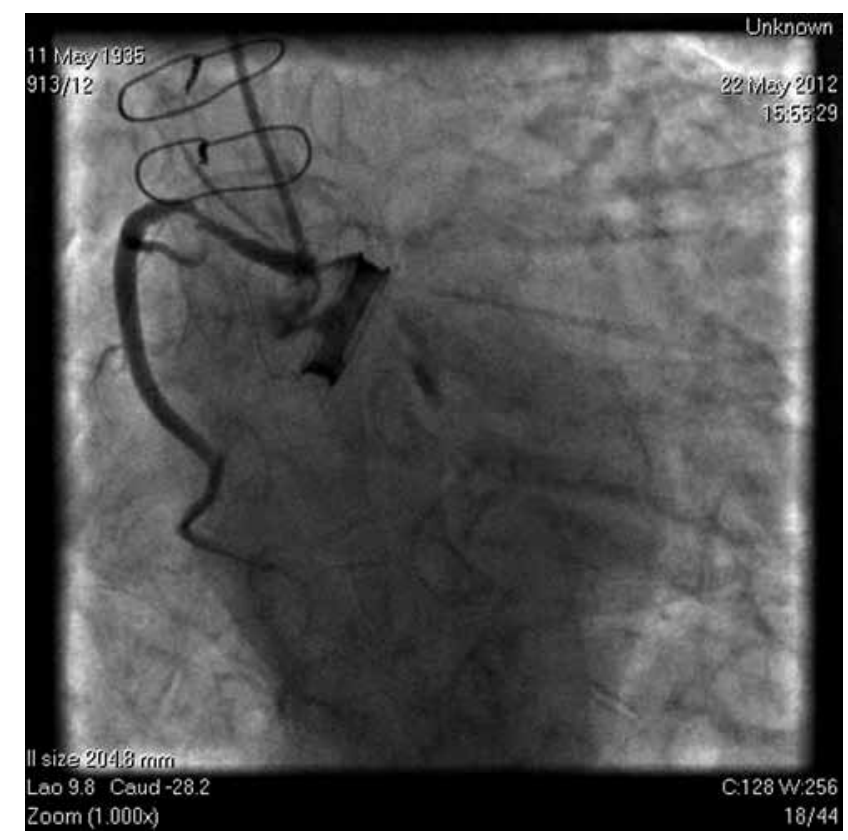

Fig. 3. Coronary angiogram: a critical stenosis of the right coronary artery

and low thrombogenicity in patients receiving effective anticoagulative treatment. In an analysis by Olesen et al. [4], the average 15-year survival after the implantation of Lillehei-Kaster aortic valves was $49 \%$ - a result comparable to Starr-Edwards and Bjork-Shiley valves. Unfortunately, the described valve had its flaws. As early as in 1976, Sigwart et al. noted that implanting adult patients with Lillehei-Kaster valves smaller than $18 \mathrm{~mm}$ may be a cause of increasing transvalvular gradients after the surgery [5]. The authors also reported that the maximal degree of valve opening (80 degrees) was not achieved in any of the 28 patients according to the postoperative hemodynamic measurements; however, this did not significantly influence the valve's functionality. On the other hand, the cardiac surgeons of the time tended to avoid oversizing, i.e. implanting valves

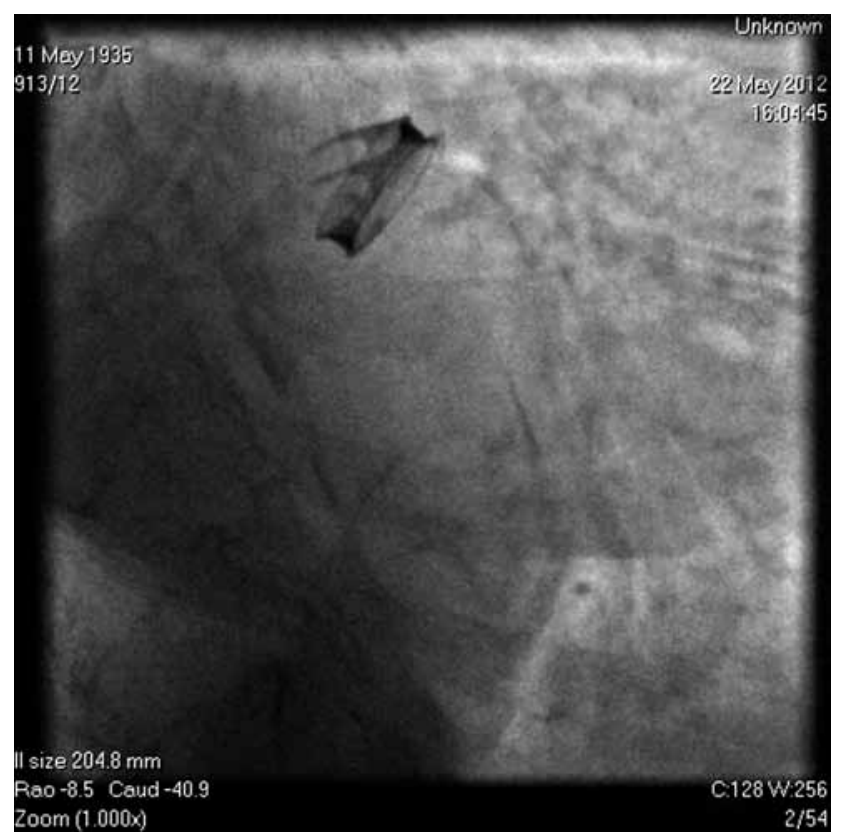

Fig. 4. Fluoroscopy: the disc of the mechanical aortic valve opening to an angle of 60 degrees

1-2 sizes larger than the valve annulus, due to the potential risk of postoperative left ventricular free wall rupture [6]. The problem of mismatch, i.e. the use of excessively small aortic prostheses that can influence long-term results, was described much later.

Some patients with aortic stenosis suffer from poststenotic ascending aortic dilatation - most commonly, this occurs in patients with concomitant aortic regurgitation or bicuspid aortic valves (BAV) and in patients after aortic valve replacement (AVR). Cardiac surgeons face the dilemma whether to perform concurrent replacement of the dilated ascending aorta in patients qualified for AVR, as it is associated with an increased risk of perioperative complications and mortality. An analysis performed by Andrus et al. [7] compared the initial and postoperative degree of 
ascending aortic dilatation in 185 patients after AVR during an observation period lasting 30 months on average. Progression of the ascending aortic aneurysm, defined as an increase in aortic diameter $>3 \mathrm{~mm}$ in relation to the initial measurement, was observed in as few as $15 \%$ of patients; none of the patients with the initial diameter of $>3.5 \mathrm{~cm}$ was diagnosed with aortic dilatation $>5.5 \mathrm{~cm}$ during the observation period. The authors concluded against routine concurrent surgery of ascending aortic dilatation in patients qualified for AVR. Slightly different conclusions were reached by Matsuyama et al. [8], who analyzed the frequency of aortic complications in 35 patients after AVR with initial aortic dilatations of $>4 \mathrm{~cm}$. The mean observation period was 8.1 years. Aortic complications occurred in 5 patients (1 dissection, 2 ruptures, 2 reoperations). The authors acknowledged that the clinical stability of ascending aortic aneurysms is uncertain, and concurrent surgery of the ascending aorta should be considered in all patients undergoing AVR with initial dilatations of $>4 \mathrm{~cm}$. In turn, Natsuaki et al. compared the frequency of aortic complications after AVR in patients with and without initial dilatations of the ascending aorta [9]. They concluded that patients undergoing AVR with initial dilatations of $>4 \mathrm{~cm}$ are at a greater risk of dissection or aneurysm enlargement, and, therefore, prophylactic aortic surgery should be considered to prevent these complications.

Another factor playing a significant role in the progression of aortic dilatation in our patient was surely arterial hypertension, which had lasted for many years. A study by Milan et al. [10] encompassed 345 patients with confirmed arterial hypertension: in as many as $17 \%$, echocardiographic examination revealed ascending aortic dilatation. Significantly higher values of systolic arterial pressure $(129.81 \pm 15.4$ vs. $125.02 \pm 14.7 \mathrm{mmHg} ; p=0.02)$ and pressure heart rate $(45.02 \pm 10.4$ vs. $42 \pm 9.54 \mathrm{mmHg} ; p=0.02)$ were observed in this group of patients as compared with the group without aortic dilatation.

In conclusion, the case described in the present study illustrates the possibility of achieving very good long-term results after the surgical treatment of aortic valve stenosis with old generation aortic valve implantation. Notwithstanding, the durability of the valve does not always prevent late complications in the form of aortic dilatation and valve function deterioration - possibly due to pannus ingrowth. Together with the inevitable progression of coronary artery atherosclerosis, this may force physicians to make difficult therapeutic decisions, as illustrated by the presented case.

\section{Disclosure}

Authors report no conflict of interest.

\section{References}

1. DeWall RA, Qasim N, Carr L. Evolution of mechanical heart valves. Ann Thorac Surg 2000; 69: 1612-1621.

2. Mikhail AA, Ellis R, Johnson S. Eighteen-year evolution from the LilleheiKaster valve to the Omni design. Ann Thorac Surg 1989; 48 (3 Suppl): S61-64.

3. Stewart S, Cianciotta D, Hicks GL, DeWeese JA. The Lillehei-Kaster aortic valve prosthesis. Long-term results in 273 patients with 1253 patient-years of follow-up. J Thorac Cardiovasc Surg 1988; 95: 1023-1030.

4. Olesen $\mathrm{KH}$, Rygg IH, Wennevold A, Nyboe J. Aortic valve replacement with the Lillehei-Kaster prosthesis in 262 patients: an assessment after 9 to 17 years. Eur Heart J 1991; 12: 680-689.

5. Sigwart U, Schmidt H, Gleichmann U, Borst HG. In vivo evaluation of the Lillehei-Kaster heart valve prosthesis. Ann Thorac Surg 1976; 22: 213-220.

6. DeWall RA, Ellis RL. Implantation techniques: a primary consideration in valve surgery. Ann Thorac Surg 1989; 48 (3 Suppl): S59-60.

7. Andrus BW, O'Rourke DJ, Dacey LJ, Palac RT. Stability of ascending aortic dilatation following aortic valve replacement. Circulation 2003; 108 Suppl 1: II295-299.

8. Matsuyama K, Usui A, Akita T, Yoshikawa M, Murayama M, Yano T, Takenaka H, Katou W, Toyama M, Okada M, Sawaki M, Ueda Y. Natural history of a dilated ascending aorta after aortic valve replacement. Circ J 2005; 69: 392-396.

9. Natsuaki M, Itoh T, Rikitake K, Okazaki Y, Naitoh K. Aortic complications after aortic valve replacement in patients with dilated ascending aorta and aortic regurgitation. J Heart Valve Dis 1998; 7: 504-509.

10. Milan A, Tosello F, Naso D, Avenatti E, Leone D, Magnino C, Veglio F. Ascending aortic dilatation, arterial stiffness and cardiac organ damage in essential hypertension. J Hypertens 2013; 31: 109-116. 